International Journal of Electrical and Power Engineering 13 (1): 1-4, 2019

ISSN: $1990-7958$

(C) Medwell Journals, 2019

\title{
Improved of Frequency Stability Response using the High Speed Valve Control (HSVC) of the Micro Hydro Power Plant
}

\author{
${ }^{1}$ Syarifuddin Nojeng, ${ }^{1}$ Sugianto, ${ }^{2}$ R.A. Reny Murniati and ${ }^{3}$ Shiddiq Yunus \\ ${ }^{1}$ Department of Electrical Engineering, Universitas Muslim Indonesia, Makassar, Indonesia \\ ${ }^{2}$ Department of Electrical Engineering, Universitas Sawerigading, Makassar, Indonesia \\ ${ }^{3}$ Department of Electrical Engineering, Politeknik Negeri Ujung Pandang, Makassar, Indonesia
}

\begin{abstract}
Micro-Hydro Power Plant (MHPP) is one of popular renewable based power plants that appropriate to be installed in developing countries such as Indonesia due to its stability, efficient operation and economic point of view. Frequency stability of power plant systems refers to the ability of generator to maintain the steady frequency during and post faults and rapid dynamic load. In order to keep the stability of power system frequency from fluctuations, generating units change their power output automatically according to the change of the system frequency or load through balancing of the active power with the loads. To keep the stability frequency on MHPP, active power fast control is employed in this study and all the system of MHPP and the frequency control are carried out and simulated extensively using MATLAB/Simulink. With the active power control through fast valving mechanism using HSVC method, duration of stability frequency response is faster compared to the system without fast control.
\end{abstract}

Key words: Frequency stability response, HSVC method, hydro power plant, renewable energy, frequency, appropriate

\section{INTRODUCTION}

Now a days, world is facing the act of detrimental effects of conventional based power plants on environment. Therefore, many countries all around the world are intensively develop the technology for renewable based power plants such solar cell, wind, biomass, etc. For example, the significant installation of wind (Yunus et al., 2012, 2011a-c; Khamaira et al., 2013) hydropower (Firman et al., 2017) and solar cell (Yunus and Saini, 2016). In Indonesia, Micro Hydropower Plants (MHPPs) become popular renewable based power plants due to its economic point of view. A MHPP is not only suitable based on the economic reason but also its location that normally close to the remote communities. Moreover with its simple and mature technology a MHPP could provide a stable and efficient power to the remote community. However, it is important to employ a proper technique to maintain the frequency stability during and post faults as well as load instability. Frequency stability of power plant systems refers to the ability of generator to maintain steady frequency during or post faults or in condition of rapid change in the dynamic load. In order to keep the power system frequency from fluctuations, generating units change their power output automatically according to the change of system frequency or load through balancing of the active power with load. This technical strategy can be achieved using active power control of MHPP. Normally an MHPP has capacity $<100 \mathrm{~kW}$ and commonly located in remote areas and connected to non-grid communities. A MHPP system, generally, consists of a synchronous generator, excitation system and turbine system with their control. As water debit usually large whereas the loads sometimes fluctuate which in turns will affect the frequency response, the fast active power control approach is suitable to be applied in MHPP. Therefore, the performance of MHPPs in terms of frequency control is very important. The research on active power control method and dynamic processes of SHPPs is of great importance. The frequency stability of MHPP is a critical factor of power system stability including the power quality for costumer. The active power response time is applied to evaluate the frequency stability and response characteristic which are two key indicators for generator performance.

Stability improvement: The synchronous stability of the synchronous generator is strongly influenced by the parameters of the synchronous machine (Chen et al., 2014). The machines parameters such as frequency, voltage and power angle will experience swing in the event of interference (Saarinen, 2014). To maintain the stability of the generator, interference must be restored before the power angle exceeds the critical severance angle (Wang et al., 1993; Park, 1973). Some of methods

Corresponding Author: Syarifuddin Nojeng, Department of Electrical Engineering, Universitas Muslim Indonesia, Makassar, Indonesia 
that can be done to improve the transition stability of the generator which are minimizing the effect of faults by minimizing the duration of interference including improve the stored synchronization mode (Demello et al., 1992). To reduce acceleration torque, an active power control can be applied for turbine by setting the mechanical power using an artificial load. Some papers proposed the hydraulic system modeling method and further investigation of the interactions between power system oscillation and the dynamic characteristics of the hydraulic mechanical system (De Jaeger et al., 1994), (Machowski et al., 1999). A study conducted in Demello et al. (1992) proposed a scheme for improving transitional stability of the system by using a method of coordination between fast valving and generator excitation setting (Matsuzawa et al., 1995). Research in proposed a fast valving method by using a parallel valve system to improve system stability. A braking resistor as part of the reduction of torque acceleration through artificial loads is proposed where this method could reduce the area of acceleration when using a breaking resistor of $0.125 \mathrm{pu}$ (Tamersi et al., 2011) introduced a design of system called the Micro Grid Voltage Stabilizer (MGVS) (Fang et al., 2008; Souza et al., 1999; Munoz-Hernandez and Jones, 2012). Have constructed nonlinear models for the transient characteristic of the hydro power plant with a focus on the influence of the surge tank. An integrated system analysis model with respect to the rotational speed and active power control during hydropower plant operation is proposed in (Strah et al., 2005). A high-order model of Hydropower Plants (HPPs) with islanded power networks operation to determine unstable operation of hydroelectric systems is proposed in (Nicolet et al., 2007). In, an approach is established to refine model for pumped storage of power plant. The study also studied the nonlinear characteristic and intensively explored the active power oscillation issue based on a pumped storage power plant. While, an operating model for grid-connected pumped storage power plants is proposed in (Perez-Diaz et al., 2014), to study the hydraulic short circuit characteristics (Kishor et al., 2007). Conducts review to several research results about modeling, control strategies, etc., as well as regulation and operation performance for HPPs. In general, the equation which states the balance of active power on the generator is expressed as follows:

$$
\mathrm{J} \omega_{\mathrm{m}} \frac{\partial^{2} \delta_{\mathrm{m}}}{\delta \mathrm{t}^{2}}=\mathrm{P}_{\mathrm{a}}=\mathrm{P}_{\mathrm{m}}-\mathrm{P}_{\mathrm{e}}
$$

Where:

$\mathrm{J}$ : Momen Inertia

$\omega_{\mathrm{m}}$ : Angle of mechanical

$\delta_{\mathrm{m}}$ : Angle of angular

$\mathrm{P}_{\mathrm{m}}$ : Mechanical Power

$\mathrm{P}_{\mathrm{e}}$ : Electrical Power

$\mathrm{P}_{\mathrm{a}}$ : Acceleration Power

\section{MATERIALS AND METHODS}

Method of controlling the mechanical power of a turbine is rapidly used to improve the stability of the generator switch. The principle work of the system is to reduce the mechanical power of the turbine with the closure of the valve (valve) quickly. The High Speed Valve Control (HSVC) mechanism uses double nozzle system with variable speed motor drive. The ability of the water valve to close and open quickly will be depended on the type of governor system used. The type of electro-hydraulic turbine governor that equipped with an electronic state drive system and a high pressure hydraulic drive is capable for fast valve control. The HSVC method can also be used in mechanical hydraulic governor turbines but it less flexible and more difficult to implement on the system Fig. 1.

\section{RESULTS AND DISCUSSION}

Data and parameters of the system under study can be seen in Table 1 time of valve mechanism (assumption):

- $\mathrm{t}=0.5 \mathrm{sec}$ ( With-out HSVC)

- $\mathrm{t}=0.25 \mathrm{sec}(\mathrm{HSVC})$

Acceleration of active power setting through valve closure and valve opening at synchronous mechanical power input of synchronous generator can improve the stability of synchronous generator.

In Fig. 2, it is shown that when the power plant loses the load suddenly of $0.2 \mathrm{pu}$, the synchronous generator will be swing for $8 \mathrm{sec}$ to return stable if without using fast valving. Meanwhile, by using fast valve acceleration, the generator will achieve stability for $4.5 \mathrm{sec}$. While, the amplitude of the rotor frequency changes reach of 0.0145 pu without fast valving. However, if using fast valving it is only change about 0.0125 pu. Figure 3 shows that when the power plant loses the load suddenly by $0.8 \mathrm{pu}$. The synchronous generator will be swing for $8 \mathrm{sec}$ until it

Table 1: Data and parameters of the system

\begin{tabular}{|c|c|c|}
\hline Parameters & & Value (pu) \\
\hline \multirow{2}{*}{ Sinkron reaktance } & $\mathrm{X}_{\mathrm{d}}$ & 0.6 \\
\hline & $X_{q}^{a}$ & 0.4 \\
\hline \multirow[t]{2}{*}{ Transient reaktance } & $X_{d}^{4}$ & 0.15 \\
\hline & $X^{\prime}$ & 0.3 \\
\hline \multirow{2}{*}{ Sub transient reactance } & $\mathrm{X}_{\mathrm{d}}^{\mathrm{q}}{ }_{\mathrm{d}}$ & 0.1 \\
\hline & $X "$ & 0.25 \\
\hline \multirow[t]{2}{*}{ Time constant of transient } & $\mathrm{T}_{\mathrm{d}}^{\mathrm{q}}$ & 3.0 \\
\hline & $\mathrm{T}^{\prime}{ }_{\mathrm{g}}^{\mathrm{a}}$ & 0.1 \\
\hline \multirow[t]{2}{*}{ Time constant of sub transient } & $T^{\prime \prime}$ & 0.01 \\
\hline & $X^{\prime \prime d ~}$ & 0.03 \\
\hline Leakage inductance & $\mathrm{X}_{1}^{\mathrm{q}}$ & 0.15 \\
\hline Resistance of stator & $\mathrm{R}_{\mathrm{a}}$ & 0.005 \\
\hline Constant of inertia & $\mathrm{H}^{a}$ & $\mathrm{n} / \mathrm{a}$ \\
\hline Constant of damp & $\mathrm{D}$ & $\mathrm{n} / \mathrm{a}$ \\
\hline
\end{tabular}




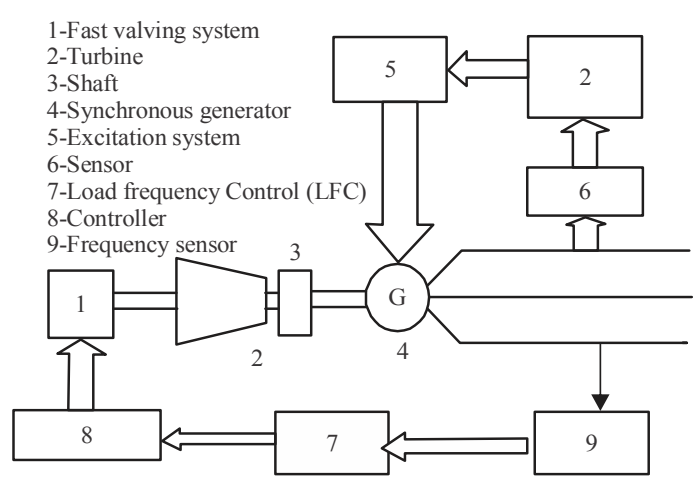

Fig. 1: Micro hydro power plant systems

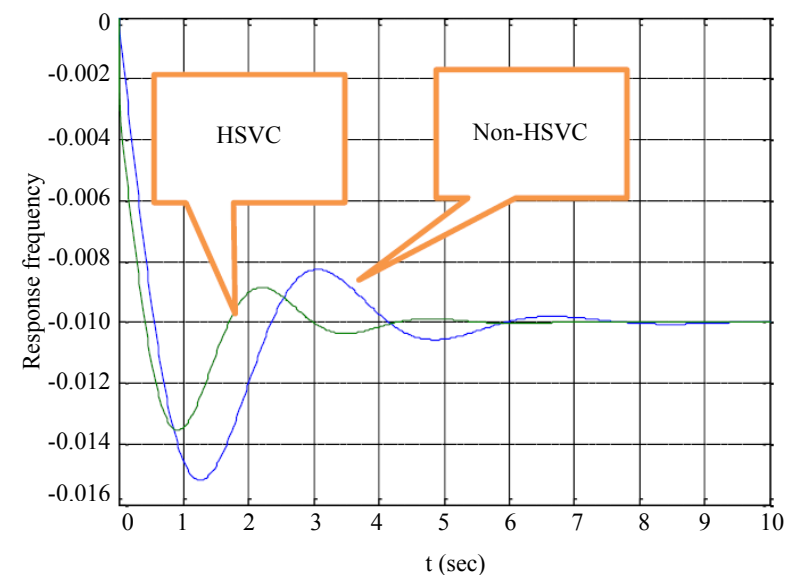

Fig. 2: Frequency response with the generator loses the load suddenly of $0.2 \mathrm{pu}$

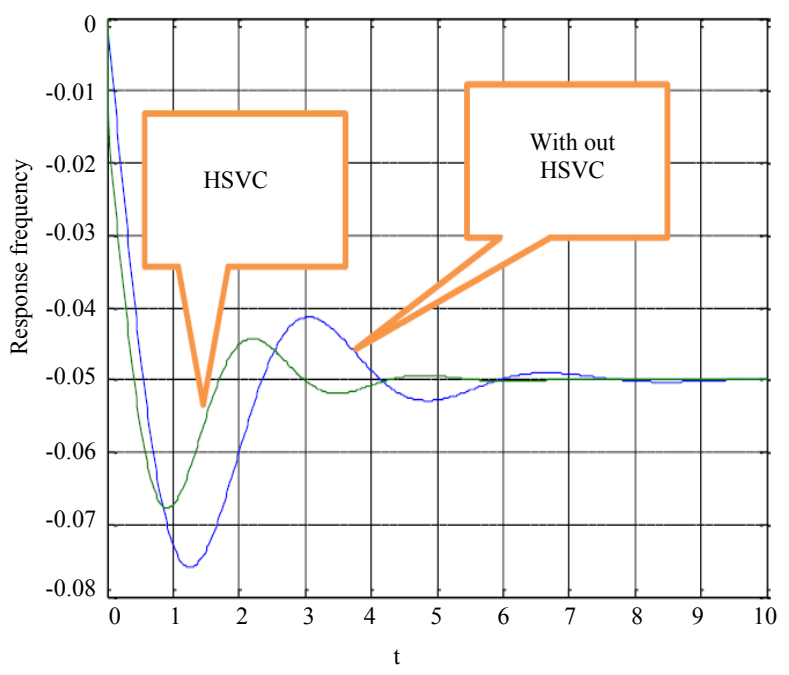

Fig. 3: Frequency response with the generator loses the load suddenly of $1.0 \mathrm{pu}$ (all loads) returns stable if without using HSVC. By using fast valve acceleration, however, the generator will achieve stable faster in $6 \mathrm{sec}$. While, the amplitude of the rotor frequency changes reached $0.06 \mathrm{pu}$ without fast valving by HSVC method. In contrast, it is only reach $0.055 \mathrm{pu}$ when using fast HSVC.

\section{CONCLUSION}

Based on the simulation using MATLAB/Simulink program, it can be concluded that: by using fast control for valve mechanism (HSVC), the mechanical power swing duration of generator will be smaller than without fast control of active power. However, a sudden power change will result a greater transient time on the generator. The mechanical power transient of turbine has smaller duration time when using fast control with fast valving than without fast control of active power

\section{ACKNOWLEDGEMENTS}

The researcher would like to thank the Ministry of Research Technology and Higher Education Ministry of Indonesia who has funded this research. The researcher would also like to thank Rector of Universitas Muslim Indonesia Makassar and also for Sawerigading Makassar for providing facilities and opportunities to conduct the research.

\section{REFERENCES}

Chen, D., C. Ding, Y. Do, X. Ma, H. Zhao and Y. Wang, 2014. Nonlinear dynamic analysis for a Francis hydro-turbine governing system and its control. J. Franklin Inst., 351: 4596-4618.

De Jaeger, E., N. Janssens, B. Malfliet and F. van de Meulebroeke, 1994. Hydro turbine model for system dynamic studies. IEEE. Trans. Power Syst., 9: 1709-1715.

Demello, F.P., R.J. Koessler, J. Agee, P.M. Anderson, J.H. Doudna, J.H. Fish and C. Taylor, 1992. Hydraulic-turbine and turbine control-models for system dynamic studies. IEEE. Trans. Power Syst., 7: 167-176.

Fang, H., L. Chen, N. Dlakavu and Z. Shen, 2008. Basic modeling and simulation tool for analysis of hydraulic transients in hydroelectric power plants. IEEE. Trans. Energy Convers., 23: 834-841.

Firman, A.S. Yunus and M.Y. Yunus, 2017. Sediment characteristic on hydropower plant Bakaru, South Sulawesi. AIP. Conf. Proc., Vol. 1788, 
Khamaira, M.Y., A.S. Yunus and A. Abu-Siada, 2013. Improvement of DFIG-based WECS performance using SMES unit. Proceedings of the 2013 Australasian Conference on Universities Power Engineering (AUPEC), September 29-October 3, 2013, IEEE, Hobart, Australia, pp: 1-5.

Kishor, N., R.P. Saini and S.P. Singh, 2007. A review on hydropower plant models and control. Renewable Sustainable Energy Rev., 11: 776-796.

Machowski, J., A. Smolarczyk and J.W. Bialek, 1999. Power system transient stability enhancement by co-ordinated fast valving and excitation control of synchronous generators. Proceedings of the CIGRE Symposium on Working Plants and Systems Harder, June 7-9, 1999, London, pp: 1-6.

Matsuzawa, K., K. Yanagihashi, J. Tsukita, M. Sato, T. Nakamura and A. Takeuchi, 1995. Stabilizing control, system preventing loss of synchronism from extension and its actual operating experience. IEEE. Trans. Power Syst., 10: 1606-1613.

Munoz-Hernandez, G.A. and D.I. Jones, 2012. Modelling and Controlling Hydropower Plants. Springer, Berlin, Germany, ISBN:978-1-4471-2290-6, Pages: 297.

Nicolet, C., B. Greiveldinger, J.J. Herou, B. Kawkabani, P. Allenbach, J.J. Simond and F. Avellan, 2007. High-order modeling of hydraulic power plant in islanded power network. IEEE. Trans. Power Syst., 22: 1870-1880.

Park, R.H., 1973. Fast turbine valving. IEEE. Trans. Power Apparatus Syst., 92: 1065-1073.

Perez-Diaz, J.I., J.I. Sarasua and J.R. Wilhelmi, 2014. Contribution of a hydraulic short-circuit pumped-storage power plant to the load-frequency regulation of an isolated power system. Intl. J. Electr. Power Energy Syst., 62: 199-211.

Saarinen, L., 2014. A hydropower perspective on flexibility demand and grid frequency control. Ph.D Thesis, Uppsala Universitet, Sweden.

Souza, O.H., N. Barbieri and A.H.M. Santos, 1999. Study of hydraulic transients in hydropower plants through simulation of nonlinear model of penstock and hydraulic turbine model. IEEE. Trans. Power Syst., 14: 1269-1272.
Strah, B., O. Kuljaca and Z. Vukic, 2005. Speed and active power control of hydro turbine unit. IEEE. Trans. Energy Convers., 20: 424-434.

Tamersi, A., G. Radman and M. Aghazadeh, 2011. Enhancement of Microgrid Dynamic Voltage Stabilty using Microgrid Voltage Stabilizer. Proceedings of the IEEE International Conference on Southeastcon, March 17-20, 2011, IEEE, Nashville, Tennessee, USA., pp: 368-373.

Wang, Y., D.J. Hill, R.H. Middleton and L. Gao, 1993. Transient stability enhancement and voltage regulation for power systems. IEEE Trans. Power Syst., 8: 620-627.

Yunus, A.S. and M. Saini, 2016. Overview of SMES units application on smart grid systems. Proceedings of the 2016 International Seminar on Intelligent Technology and its Applications (ISITIA), July 28-30, 2016, IEEE, Lombok, Indonesia, pp: 465-470.

Yunus, A.S., A. Abu-Siada and M.A. Masoum, 2011c. Improvement of LVRT capability of variable speed wind turbine generators using SMES unit. Proceedings of the 2011 IEEE PES International Conference on Innovative Smart Grid Technologies, November 13-16, 2011, IEEE, Perth, Australia, pp: 1-7.

Yunus, A.S., A. Abu-Siada and M.A.S. Masoum, 2011a. Effect of SMES unit on the performance of type 4 wind turbine generator during voltage sag. Proceedings of the IET Conference on Renewable Power Generation (RPG'11), September 6-8, 2011, Edinburgh, UK., pp: 1-4.

Yunus, A.S., A. Abu-Siada and M.A.S. Masoum, 2011 b. Effects of SMES on dynamic behaviors of type D-Wind Turbine Generator-Grid connected during short circuit. Proceedings of the 2011 IEEE International General Meeting on Power and Energy Society, July 24-28, 2011, IEEE, Detroit, Michigan, USA., pp: 1-6.

Yunus, A.S., A. Abu-Siada and M.A.S. Masoum, 2012. Improving dynamic performance of wind energy conversion systems using fuzzy-based hysteresis current-controlled superconducting magnetic energy storage. IET. Power Electron., 5: 1305-1314. 